\title{
Thermodynamic Studies on Simultaneous Desulfurization and Denitrification by Chlorine-based Composite
}

\author{
Yunyang Wang \\ North China Electric Power University, Baoding, China
}

\begin{abstract}
This paper studied the reaction mechanism and got the overall reaction equation based on the experimental study and the analysis results of desulfurization and denitrification by chlorine-based composite. And studied the chemical and thermodynamic properties of simultaneous desulfurization and denitrification by chlorine-based composite on the basic of chemical and thermodynamic principle. The desulfurization and denitrification by chlorine-based compositeis method is feasible seen from the point of view of thermodynamics. The rise of temperature is not conducive to the chemical reaction.
\end{abstract}

KEYWORD: Sodium chlorite, sodium chlorate, desulfurization and denitrification, reaction mechanism, thermodynamics

\section{INTRODUCTION}

A large number of sulfur dioxide $\left(\mathrm{SO}_{2}\right)$ and nitrogen oxides (NOx) emissions from fossil fuel combustion is the main cause of air pollution[1]. After years of efforts, the gaseous emissions of large coal-fired power station has reached the effective control[2]. But due to the large quantity, wide distribution and low affordability, as the second largest source of atmospheric pollution, small and medium sized coalfired industrial boilersits' pollution control is still in its infancy[3]. Thus it has important theoretical significance and application value to develop an efficient, economical, and safe application of coal-fired industrial boilers' desulfurization and denitrification technology for air pollution control.

Sodium chlorate $\left(\mathrm{NaClO}_{3}\right)$ is a strong oxidizing solid. It is affordable and can be storaged and transported conveniently. Besides, the operating conditions of $\mathrm{NaClO}_{2} / \mathrm{NaClO}_{3}$ system matches the limestone slurry better.It can achieve efficient removal of NOx without changing the existing condition of the body structure and desulfurization system operating conditions. Thus greatly reducing the investment and operating cost of the system for denitrification. In our previous study, we studied the simultaneous desulfurization and denitrification reaction in the bubbling reactor using low concentrations of $\mathrm{NaClO}_{2}$ and $\mathrm{NaClO}_{3}$ mixed solution and accessed a higher efficiency of simultaneous desulfurization and denitrification. The removal products are mainly sulfate ions, nitrate ions and chloride ions. Based on the preliminary findings, we speculated $\mathrm{NaClO}_{2} / \mathrm{NaClO}_{3}$ simultaneous desulfurization and denitration reaction mechanism and obtain the overall reaction equation; studied the chemical thermodynamic properties of $\mathrm{NaClO}_{2} / \mathrm{NaClO}_{3}$ simultaneous desulfurization and denitration reaction. Thus made the accurt judgments of the direction and degree of chemical reactions, providing a theoretical basis for $\mathrm{NaClO}_{2} / \mathrm{NaClO}_{3}$ simultaneous desulfurization and denitration technology's optimization and development.

\section{REACTION MECHANISM}

\subsection{Redox trend analysis}

Standard electrode potential of $\mathrm{SO}_{2}, \mathrm{NO}, \mathrm{NaClO}_{2}$, $\mathrm{NaClO}_{3}$ and other species may existed during the reaction are shown in Table 1. 
Table 1 Related Redox Electrode Potential [4,5]

\begin{tabular}{cccccccc}
\hline Redox & $\mathrm{NO}_{3}{ }^{-} / \mathrm{NO}_{2}$ & $\mathrm{NO}_{3}{ }^{-} / \mathrm{NO}$ & $\mathrm{NO}_{2} / \mathrm{NO}$ & $\mathrm{SO}_{4}{ }^{2-} / \mathrm{SO}_{3}{ }^{2-}$ & $\begin{array}{c}\mathrm{ClO}^{2} / \mathrm{Cl}^{-} \\
\text {(acidity) }\end{array}$ & $\begin{array}{c}\mathrm{ClO}_{2} / \mathrm{Cl}^{-} \\
\text {(acidity) }\end{array}$ & $\begin{array}{c}\mathrm{ClO}_{3}{ }^{-} / \mathrm{Cl}^{-} \\
\text {(acidity) }\end{array}$ \\
\hline $\begin{array}{c}\text { Electrode potential } \\
\Phi_{\mathrm{A}}(\mathrm{eV})\end{array}$ & 0.94 & 0.96 & 1.07 & 0.93 & 1.570 & 1.511 & 1.45 \\
\hline
\end{tabular}

As Table 1 shows, the electric potential of $\mathrm{ClO}_{2}{ }^{-}$ $/ \mathrm{Cl}^{-}$(Acidity), $\mathrm{ClO}_{2}{ }^{-} / \mathrm{ClO}^{-}$(Acidity) and $\mathrm{ClO}_{3}{ }^{-} / \mathrm{Cl}^{-}$ (Acidity) electrode pairs is significantly higher than $\mathrm{SO}_{4}{ }^{2-} / \mathrm{SO}_{3}{ }^{2-}, \mathrm{NO}_{2} / \mathrm{NO}, \mathrm{NO}_{3}{ }^{-} / \mathrm{NO}, \mathrm{NO}_{3}{ }^{-} / \mathrm{NO}_{2}{ }^{-}$and other redox electrode pairs. Meanwhile, $\mathrm{NaClO}_{2}$ and $\mathrm{NaClO}_{3}$ is easy to decompose into chlorine dioxide $\left(\mathrm{ClO}_{2}\right)$ in the acidic environment. And $\mathrm{ClO}_{2}$ has strong oxidation than $\mathrm{ClO}_{2}{ }^{-}$and $\mathrm{ClO}_{3}{ }^{-}$in the acidic environment. Therefore, $\mathrm{SO}_{2}$ and $\mathrm{NO}$ can be oxidized to their highest valence state when passing the $\mathrm{NaClO}_{2} / \mathrm{NaClO}_{3}$ solution.

\subsection{Reaction Process}

It can be confirmed that it indeed carried out the reaction of $\mathrm{NO}$ and $\mathrm{SO}_{2}$ removal in the bubbling reactor combined with the removal efficiency experiments and the analysis results of reaction product, the main products of desulfurization and denitrification were $\mathrm{SO}_{4}{ }^{2-}$ and $\mathrm{NO}_{3}{ }^{-} . \mathrm{ClO}_{2}{ }^{-}$and $\mathrm{ClO}_{3}{ }^{-}$were changed into $\mathrm{Cl}^{-}$after the reaction.

$\mathrm{NaClO}_{3}$ and $\mathrm{NaClO}_{2}$ have low concentration in this experiment, and the $\mathrm{pH}$ of the solution is higher than 4. Thus almost no $\mathrm{ClO}_{2}$ and $\mathrm{Cl}_{2}$ diffuse from liquid phase to gas phase, namely that redox reactions in the gas phase can be negligible. Therefore, this paper focuses on the reaction mechanism in the liquid phase.

$\mathrm{NaClO}_{2}$ and $\mathrm{NaClO}_{3}$ have strong oxidizing power in the acidic environment. They can produce strong oxidizing intermediate species through a series of reactions like $\mathrm{ClO}_{2}$. The main reaction mechanisms are presumed as follows:

$$
\begin{aligned}
& \mathrm{NaClO}_{3}+2 \mathrm{HCl} \rightarrow \mathrm{ClO}_{2} \uparrow+1 / 2 \mathrm{Cl}_{2} \uparrow+\mathrm{NaCl}+\mathrm{H}_{2} \mathrm{O} \\
& 11 \mathrm{NaClO}_{2}+8 \mathrm{HCl} \rightarrow 4 \mathrm{ClO}_{2}+4 \mathrm{HClO}_{3}+11 \mathrm{NaCl}+2 \mathrm{H}_{2} \mathrm{O} \\
& 2 \mathrm{NaClO}_{2}+\mathrm{Cl}_{2} \rightarrow 2 \mathrm{NaCl}+2 \mathrm{ClO}_{2}
\end{aligned}
$$

Based on the reaction mechanism presumed above, the possible substances existed in acidic $\mathrm{NaClO}_{2} / \mathrm{NaClO}_{3}$ solution include $\mathrm{ClO}_{2}{ }^{-}, \mathrm{ClO}_{3}{ }^{-}, \mathrm{ClO}_{2}$, $\mathrm{Cl}_{2}$ and perchlorate $\left(\mathrm{HClO}_{3}\right)$, etc. $\mathrm{ClO}_{2}{ }^{-}$and $\mathrm{ClO}_{3}{ }^{-}$in acidic environment can produce $\mathrm{ClO}_{2}$ or $\mathrm{Cl}_{2}$ through a series of reactions. Since the intermediates $\mathrm{ClO}_{2}$ and $\mathrm{Cl}_{2}$ both have strong oxidizing power, the removal rate of simultaneous desulfurization and denitrification process improved significantly.

$\mathrm{SO}_{2}$ is a relatively soluble gas, and its reaction with $\mathrm{ClO}_{2}^{-}, \mathrm{ClO}_{3}{ }^{-}$and $\mathrm{ClO}_{2}$ belongs to extremely fast irreversible reaction. It is rapidly oxidized when entering the film, resulting in a concentration gradient increases. Thereby increased the gas-liquid mass transfer rate. Based on the above conditions, the overall reaction equations of desulfurization by $\mathrm{NaClO}_{3} / \mathrm{NaClO}_{2}$ are considered as follows:

$$
\begin{aligned}
& 2 \mathrm{NaClO}_{3}+\mathrm{SO}_{2} \rightarrow 2 \mathrm{ClO}_{2}+\mathrm{Na}_{2} \mathrm{SO}_{4} \\
& 5 \mathrm{SO}_{2}+2 \mathrm{ClO}_{2}+6 \mathrm{H}_{2} \mathrm{O} \rightarrow 5 \mathrm{H}_{2} \mathrm{SO}_{4}+2 \mathrm{HCl} \\
& 2 \mathrm{SO}_{2}(\mathrm{~g})+\mathrm{NaClO}_{2}(\mathrm{aq})+2 \mathrm{H}_{2} \mathrm{O}(\mathrm{l}) \rightarrow 2 \mathrm{H}_{2} \mathrm{SO}_{4}(\mathrm{aq})+\mathrm{NaCl}(\mathrm{aq})
\end{aligned}
$$

NO is a difficult material to be absorbed by water or lye. But it can obtain a high NO removal rate in a short time. Thus there may be a process that NO is rapidly oxidized to water-soluble substances (such as $\mathrm{NO}_{2}$, etc.) first, and then being absorbed by the absorbent.

Based on the previous findings[6], the overall reaction equations of denitration by $\mathrm{NaClO}_{3} / \mathrm{NaClO}_{2}$ are considered as follows:

$$
\begin{aligned}
& 2 \mathrm{NO}+2 \mathrm{ClO}_{2}^{-}+\mathrm{H}_{2} \mathrm{O} \rightarrow 2 \mathrm{HNO}_{3}+\mathrm{Cl}^{-}+\mathrm{ClO}^{-} \\
& 2 \mathrm{NO}+3 \mathrm{ClO}^{-}+\mathrm{H}_{2} \mathrm{O} \rightarrow 2 \mathrm{HNO}_{3}+3 \mathrm{Cl}^{-} \\
& 5 \mathrm{NO}+3 \mathrm{ClO}_{2}+4 \mathrm{H}_{2} \mathrm{O} \rightarrow 5 \mathrm{HNO}_{3}+\mathrm{HCl}
\end{aligned}
$$

Based on the reaction mechanism presumed above, the overall reaction equations of simultaneous desulfurization and denitration by $\mathrm{NaClO}_{3} / \mathrm{NaClO}_{2}$ acid solution are considered as follows:

$5 \mathrm{SO}_{2}(\mathrm{~g})+\mathrm{NaClO}_{2}(1)+\mathrm{NaClO}_{3}(1)+5 \mathrm{H}_{2} \mathrm{O}(1) \rightarrow 5 \mathrm{H}_{2} \mathrm{SO}_{4}(1)+2 \mathrm{NaCl}(1)(10)$

$10 \mathrm{NO}(\mathrm{g})+3 \mathrm{NaClO}_{2}(\mathrm{l})+3 \mathrm{NaClO}_{3}(1)+5 \mathrm{H}_{2} \mathrm{O}(\mathrm{l}) \rightarrow 10 \mathrm{HNO}_{3}(1)+6 \mathrm{NaCl}(1)(11)$

\section{THERMODYNAMIC ANALYSIS AND CALCULATION}

\subsection{Chemical reaction enthalpy}

The standard molar reaction enthalpy $\Delta_{\mathrm{r}} \mathrm{H}_{\mathrm{m}}{ }^{\Theta}$ of constant pressure and variable temperature chemical reaction and the enthalpy $\Delta_{\mathrm{r}} \mathrm{H}_{\mathrm{m}}(\mathrm{T})$ at certain temperature can be determined by the following formula. The Standard enthalpy and the isobaric heat capacity of various substances participating in the reaction are shown in Table 2. Given that there is no isobaric heat capacity value about $\mathrm{NaClO}_{3}$ and $\mathrm{NaClO}_{2}$, we use the isobaric heat capacity value of a similar material, $\mathrm{NaClO}_{4}$.

$$
\Delta_{\mathrm{r}} \mathrm{H}_{\mathrm{m}}^{\Theta}(\mathrm{T})=\Delta_{\mathrm{r}} \mathrm{H}_{\mathrm{m}}^{\Theta}+\Delta_{\mathrm{r}} \mathrm{C}_{\mathrm{p}, \mathrm{m}} \Delta \mathrm{T}
$$


Table 2 The standard formation enthalpy, standard molar Gibbs function, standard molar entropy and heat capacity of substances

\begin{tabular}{ccccc}
\hline substances & $\Delta_{\mathrm{f}} \mathrm{H}_{\mathrm{m}}{ }^{\Theta}(\mathrm{kJ} / \mathrm{mol})$ & $\Delta_{\mathrm{f}} \mathrm{G}_{\mathrm{m}}{ }^{\Theta}(\mathrm{kJ} / \mathrm{mol})$ & $\mathrm{S}_{\mathrm{m}}{ }^{\Theta}(\mathrm{J} /(\mathrm{K} \cdot \mathrm{mol}))$ & $\mathrm{C}_{\mathrm{p}, \mathrm{m}}{ }^{\Theta}(\mathrm{J} /(\mathrm{K} \cdot \mathrm{mol}))$ \\
\hline $\mathrm{NaCl}(\mathrm{aq})$ & -407.27 & -393.17 & 115.5 & -90.0 \\
$\mathrm{SO}_{2}(\mathrm{~g})$ & -296.81 & -300.13 & 248.223 & 39.88 \\
$\mathrm{H}_{2} \mathrm{SO}_{4}(\mathrm{aq})$ & -909.27 & -744.63 & 20.1 & 293 \\
$\mathrm{NaClO}_{2}(\mathrm{aq})$ & -306.7 & -244.8 & 160.3 & -- \\
$\mathrm{NaClO}_{3}(\mathrm{aq})$ & -344.09 & -269.91 & 221.3 & -- \\
$\mathrm{NO}_{(\mathrm{g})}$ & 91.29 & 87.60 & 210.76 & 29.85 \\
$\mathrm{H}_{2} \mathrm{O}(\mathrm{l})$ & -285.830 & -273.14 & 69.95 & 75.35 \\
$\mathrm{NaClO}_{4}(\mathrm{cr})$ & -383.3 & -254.9 & 142.3 & 111.3 \\
$\mathrm{HNO}_{3}(\mathrm{aq})$ & -207.36 & -111.34 & 146.4 & -86.6 \\
\hline
\end{tabular}

We can get the following conclusions for the reaction (10):

$$
\Delta_{\mathrm{r}} \mathrm{C}_{\mathrm{p}, \mathrm{m}}{ }^{\Theta}=486.25 \mathrm{~J} /(\mathrm{K} \cdot \mathrm{mol}), \Delta_{\mathrm{f}} \mathrm{H}_{\mathrm{m}}{ }^{\Theta}=-1796.9 \mathrm{~kJ} / \mathrm{mol}
$$

When it is at the optimum reaction temperature of desulfurization and denitration, namely $323.15 \mathrm{~K}$, we can get the following conclusions:

$\Delta_{\mathrm{r}} \mathrm{H}_{\mathrm{m}}{ }^{\Theta}(323.15 \mathrm{~K})=-1784.74 \mathrm{~kJ} / \mathrm{mol}$

Similarly, for reaction (11), the values of $\Delta_{\mathrm{r}} \mathrm{C}_{\mathrm{p}, \mathrm{m}}$, $\Delta_{\mathrm{r}} \mathrm{H}_{\mathrm{m}}{ }^{\Theta}$ and $\Delta_{\mathrm{r}} \mathrm{H}_{\mathrm{m}}{ }^{\Theta}(323.15 \mathrm{~K})$ are $-2749.05 \mathrm{~J} /(\mathrm{K} \cdot \mathrm{mol})$, $-2048.6 \mathrm{~kJ} / \mathrm{mol}$ and $-2117.33 \mathrm{~kJ} / \mathrm{mol}$.

It can be judged that they are exothermic reactions because of the values of $\Delta_{\mathrm{r}} \mathrm{H}_{\mathrm{m}}{ }^{\Theta}$ and $\Delta_{\mathrm{r}} \mathrm{H}_{\mathrm{m}}{ }^{\Theta}(323.15 \mathrm{~K})$ of each reaction is less than 0 . Raising the temperature is not conducive to the reaction purely from the viewpoint of thermodynamics, and the experimental phenomena also explains the results.

\subsection{Gibbs function of the chemical reaction}

The standard Gibbs function of molar reaction $\Delta_{\mathrm{r}} \mathrm{G}$ $\mathrm{m}^{\Theta}$ and $\Delta_{\mathrm{r}} \mathrm{Gm}_{\mathrm{m}}{ }^{\Theta}(\mathrm{T})$ can be calculated by the following equation:

$$
\begin{aligned}
& \Delta_{\mathrm{r}} \mathrm{G}_{\mathrm{m}}^{\Theta}=\sum_{\mathrm{B}} v_{\mathrm{B}} \Delta_{\mathrm{f}} \mathrm{G}_{\mathrm{m}}^{\Theta}(\mathrm{B}) \\
& \Delta_{\mathrm{r}} \mathrm{G}_{\mathrm{m}}^{\Theta}(\mathrm{T})=\Delta_{\mathrm{r}} \mathrm{H}_{\mathrm{m}}^{\Theta}(\mathrm{T})-\mathrm{T} \Delta_{\mathrm{r}} \mathrm{S}_{\mathrm{m}}^{\Theta}(\mathrm{T}) \\
& \Delta_{\mathrm{r}} \mathrm{S}_{\mathrm{m}}^{\Theta}=\sum_{\mathrm{B}} \nu_{\mathrm{B}} \mathrm{S}_{\mathrm{m}}^{\Theta}(\mathrm{B})
\end{aligned}
$$

$$
\Delta_{\mathrm{r}} \mathrm{S}_{\mathrm{m}}^{\Theta}(\mathrm{T})=\Delta_{\mathrm{r}} \mathrm{S}_{\mathrm{m}}^{\Theta}+\Delta_{\mathrm{r}} \mathrm{C}_{\mathrm{p}, \mathrm{m}} \ln \frac{\mathrm{T}}{298.15}
$$

Values of standard Gibbs function and standard entropy of each substance participating in the reaction are shown in Table 2.

We can get the following conclusions for reaction (10):

$$
\begin{aligned}
& \Delta_{\mathrm{r}} \mathrm{G}_{\mathrm{m}}{ }^{\Theta}=-1128.43 \mathrm{~kJ} / \mathrm{mol}, \\
& \Delta_{\mathrm{r}} \mathrm{S}_{\mathrm{m}}{ }^{\Theta}=-1640.965 \mathrm{~J} /(\mathrm{K} \cdot \mathrm{mol})
\end{aligned}
$$

When it is at the optimum reaction temperature of desulfurization and denitration, namely $323.15 \mathrm{~K}$, we can get the following conclusions:

$\Delta_{\mathrm{r}} \mathrm{S}_{\mathrm{m}}{ }^{\Theta}(323.15 \mathrm{~K})=-1.602 \mathrm{~kJ} /(\mathrm{K} \cdot \mathrm{mol})$,

$\Delta_{\mathrm{r}} \mathrm{G}_{\mathrm{m}}{ }^{\Theta}(323.15 \mathrm{~K})=-1267.05 \mathrm{~kJ} / \mathrm{mol}$

Similarly, for reaction (11), the values of $\Delta_{\mathrm{r}} \mathrm{G}_{\mathrm{m}}{ }^{\Theta}$, $\Delta_{\mathrm{r}} \mathrm{S}_{\mathrm{m}}{ }^{\Theta}, \Delta_{\mathrm{r}} \mathrm{S}_{\mathrm{m}}{ }^{\Theta}(323.15 \mathrm{~K})$ and $\Delta_{\mathrm{r}} \mathrm{G}_{\mathrm{m}}{ }^{\Theta}(323.15 \mathrm{~K})$ are $1438.59 \mathrm{~kJ} / \mathrm{mol},-1.445 \mathrm{~kJ} /(\mathrm{K} \cdot \mathrm{mol}),-1.666 \mathrm{~kJ} /(\mathrm{K} \cdot \mathrm{mol})$ and $-1578.96 \mathrm{~kJ} / \mathrm{mol}$.

It can be known by the above calculation results that the values of $\Delta_{\mathrm{r}} \mathrm{G}_{\mathrm{m}}{ }^{\Theta}$ and $\Delta_{\mathrm{r}} \mathrm{G}_{\mathrm{m}}{ }^{\Theta}(323.15 \mathrm{~K})$ are much smaller than $-40 \mathrm{~kJ} / \mathrm{mol}$ in the $\mathrm{NaClO}_{2} / \mathrm{NaClO}_{3}$ solution of simultaneous desulfurization and denitrification reaction [8], so the reaction (10) and (11) can be carried out and the limits is deep.

\subsection{Calculation of chemical reaction equilibrium constant}

The standard chemical reaction equilibrium constant can be calculated by the standard molar Gibbs function:

$$
\begin{aligned}
& \mathrm{K}^{\Theta}=\exp \left[-\frac{\Delta_{\mathrm{r}} \mathrm{G}_{\mathrm{m}}^{\Theta}}{\mathrm{RT}}\right] \\
& \Delta_{\mathrm{r}} \mathrm{G}_{\mathrm{m}}^{\Theta}=-\mathrm{RT} \ln \mathrm{K}^{\Theta}
\end{aligned}
$$

We can get the following conclusion according to the formula (19):

$\ln \mathrm{K}^{\Theta}=-\frac{\Delta_{\mathrm{r}} \mathrm{G}_{\mathrm{m}}^{\Theta}}{\mathrm{RT}}$

We can get the following conclusions for reaction (10):

$\ln \mathrm{K}^{\Theta}=-(-1128.43 \times 1000) /(8.314 \times 298.15)=455.23$,

$\mathrm{K}^{\Theta}=\mathrm{e}^{455.23}$.

When

$\mathrm{T}=323.15 \mathrm{~K}$,

$\operatorname{lnK}=-(-1267.05 \times 1000) /(8.314 \times 323.15)=471.61$, 
$\mathrm{K}^{\Theta}=\mathrm{e}^{471.61}$.

Similarly, for the reaction (11), the values of $\mathrm{K}^{\Theta}$ and $\mathrm{K}(323.15 \mathrm{~K})$ are $\mathrm{e}^{580.35}$ and $\mathrm{e}^{587.7}$.

We can know that every value of the equilibrium constant is big by the results calculated. Therefore, the reaction can be carried forward and be carried out more completely.

\section{SUMMARY}

This paper calculated and analyzed the chemical reaction enthalpy change, Gibbs function of chemical reactions and chemical reaction equilibrium constants and other thermodynamic parameters based on the $\mathrm{NaClO}_{2} / \mathrm{NaClO}_{3}$ solution of simultaneous desulfurization and denitrification reaction and the thermodynamic principles. The chemical reaction enthalpy results show that $\mathrm{NaClO}_{2} / \mathrm{NaClO}_{3}$ solution of simultaneous desulfurization and denitrification reaction is an exothermic reaction. Simply raising the temperature of the reaction is adversely. The chemical Gibbs function results show that the simultaneous desulfurization and denitration reaction can be carried out in the standard state and the optimum reaction temperature $(323.15 \mathrm{~K})$. And the limit is deep. The equilibrium constant values of $\mathrm{NaClO}_{2} / \mathrm{NaClO}_{3}$ solution of simultaneous desulfurization and denitration reaction are very large, from which we can get that the reaction can be carried forward, and the reaction was more complete. Therefore, $\mathrm{NaClO}_{2} / \mathrm{NaClO}_{3}$ solution of simultaneous desulfurization and denitrification reaction is feasible from the point of thermodynamic view.

\section{REFERENCES}

[1] Desulfurization denitration committee of China's environmental protection industry association. Development Report on China Desulfurization and Denitration Industries in 2013. China Environmental Protection Industry.2014, (9):4-15.

[2] Chen Y F, Zhu T Y, Cheng J,et al. Reflections on the Air Pollution Control Technology. CHINESE ACADEMY. 2013, 3(28):364-370.

[3] Zuo P L,Yue T, Han B J,et al. Study on Control Program for Air Pollutants from Coal-fired Industrial Boilers. Environmental Pollution \& Control. 2013, 35(8):100-104.

[4] Yin Y J. Handbook of Chemistry[M]. Shandong Science and Technology Press.1985, 2:731-906.

[5] J.A.Dean. Lange's Chemistry Handbook [M].Science Press. 1998, 15:8.123.

[6] Zhao Y, Guo T X, Liu F,et al. Performance of simultaneous desulfurization and denitration in liquid phase with newstyle complex absorbent. Sci China Tech Sci. 2011, 54:3009-3016, doi: 10.1007/s11431-011-4529-3.

[7] J.A.Dean.Lange's Chemistry Handbook[M].Science Press.1998,15:6.134.

[8] Li D Z. Chemical thermodynamics. Beijing Normal University Press.1982.4-95. 